\title{
The Hedonist Life of the Rulers in the Qur'an Perspective
}

\author{
Mustaqimah $^{1}$, Muhammad Obie ${ }^{* 2}$ \\ ${ }^{1}$ Department of Qur'an and Tafsir, State Islamic University of Sultan Amai Gorontalo, Indonesia \\ ${ }^{2}$ Department of Sociology, State Islamic University of Sultan Amai Gorontalo, Indonesia \\ *Corresponding Author Email: obiclimber@gmail.com
}

\section{Article Info}

Volume 7, Issue 6

Page Number: 222-233

Publication Issue :

November-December-2020

\section{Article History}

Accepted : 15 Nov 2020

Published : 25 Nov 2020

\section{ABSTRACT}

This study analyzed the hedonist life of the rulers in the Qur'an. Researchers used library research related to hedonism in the perspective of the Qur'an. The method used was the maudhu'i (thematic) method, which is a method in which the mufassir seeks to collect verses from the Qur'an from various surahs and those related to predetermined issues or topics. Allah Almighty has described the nature of the wrongdoers who perform hedonic behavior swaying in pleasure and luxury. Allah Almighty very hates hedonic behavior. Nowadays, hedonism seems to be an ideology for young people. They do not feel taboo to do. They claim themselves as Moslem, but the Moslem lifestyle is not reflected in their daily life. Mainly when they do their business, they change to be more materialistic and satisfy their biological need. They behave into two roles, religion yes and hedonism yes. The hedonism acts as a religious man, but at the same time, they also make status as hedonism. Therefore, when entering the world of hedonists, religion has the right to be defeated or marginalized and replaced by a lifestyle of framed hedonism.

Keywords: Hedonism, Materialistic, The Rulers, Qur'an Perspective

\section{INTRODUCTION}

Islam is a very comprehensive and universal religion. Its teaching system is complete and perfect. Its adherents do not only recognize this fact, but its opponents also admit the awesomeness of Islam teachings that are loaded with noble values. Evidence, both exact and non-exact aspects, show the truth and relevance of Islam to the environment. All various problems can be resolved certainly and completely by Islam.

However, in community life, nation, or state, sometimes the Muslims face the phenomena that cannot provide solutions to humanitarian problems. It is happening because of Islam's limitations to embody the values of Islamic teachings in their daily lives. Moreover, the faith quality of Islam followers is

Copyright: () the author(s), publisher and licensee Technoscience Academy. This is an open-access article distributed under the terms of the Creative Commons Attribution Non-Commercial License, which permits unrestricted noncommercial use, distribution, and reproduction in any medium, provided the original work is properly cited 
different. Allah SWT has stated firmly in Qur'an Surah At-Taghabun/64:2

"It is He who created you, and among you is the disbeliever, and among you is the believer. And Allah, of what you do, is seeing."

The difference between other automatically will create chaos and hostility among people in the world. The chaos and hostility will exist in human life until doomsday comes. Allah Almighty confirms in Qur'an Surah al-Mujadila / 58: 22

\begin{abstract}
"You will not find a people who believe in Allah and the Last Day having affection for those who oppose Allah and His Messenger, even if they were their fathers or their sons or their brothers or their kindred. Those - He has decreed within their hearts faith and supported them with spirit from Him. And We will admit them to gardens beneath which rivers flow, wherein they abide eternally. Allah is pleased with them, and they are pleased with Him those are the party of Allah. Unquestionably, the party of Allah - they are successful."
\end{abstract}

Likewise, the disbelievers will not stop trying to extinguish the light of Allah on earth's face. Qur'an Surah As Saf 61:8

"They want to extinguish the light of Allah with their mouths, but Allah will perfect His light, although the disbelievers dislike it."

If it observed, youth, poor or rich, nobles or commoners, scholars or the proletariat, in the village or the city as if agreeing to make hedonism that is true the habits of life of the western people as "role models" in the association. Allah has said in Qur'an, Surah Hood 11:116

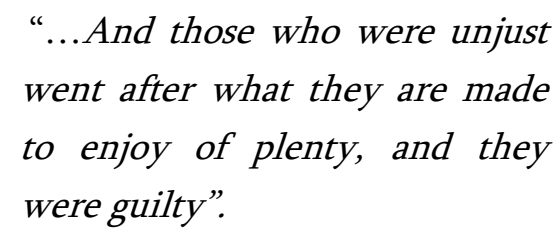

Nowadays, hedonism seems to be an ideology for young people. They do not feel taboo to do. They claim themselves as Moslem, but the Moslem lifestyle is not reflected in their daily life. Mainly when they do their business, they change to be more materialistic and satisfy their biological need. They behave into two roles, religion yes and hedonism yes. The hedonism acts as a religious man, but at the same time, they also make status as hedonism. Therefore, when entering the world of hedonists, religion has the right to be defeated or marginalized and replaced by a lifestyle of framed hedonism. That principle seems to be gaining the highest place in television shows today.

Many youths are still influenced by liberal and hedonist lifestyles. They practice uncivilized character, exclude from their nature as human beings, and destroy Allah SWT laws. The youth is running over by the flow of hedonism; They are challenging to get out of that condition. In the name of freedom, many teenagers are trapped in promiscuity, drugs, abortion, and glare with the glitter of liberal democracy. Teenagers, as the next generation of the nation, must be saved. 
Existing research deals with the hedonistic life of adolescents. Saputri \& Rachmatan (2016) examined the topic "Religiosity with a hedonistic lifestyle: a description of students at the University of Syiah Kuala." The results showed a negative relationship between religiosity with the hedonistic lifestyle of students at Syiah Kuala University. It explains that the higher the student religiosity, the lower the hedonism lifestyle will be. Vice versa, the lower the student's religiosity, the more high hedonism lifestyle too. Anggraini (2019) also conducted research related to hedonistic behavior among students. The results show a pattern of student behavior as clubbers now divided into two areas: the front stage and the backstage. On the front stage, clubbers students present themselves according to their social status, namely as students and following the general values in society. Meanwhile, there are hidden activities backstage, namely visiting night clubs, which on average are carried out 2 to 3 times a week. Some of the activities carried out at the night club include smoking, enjoying songs, drinking alcohol, dancing.

Other research deals with hedonism in consumer behavior (Subawa et al., 2020). The results showed a change in the consumer community's behavior, which was influenced by global cultural imperialism. Putra et al. (2020) examined the hedonism lifestyle in financial management found that the hedonism lifestyle had a terrible impact on financial management. Meanwhile, Caruana et al. (2020) discussed alternative hedonism in the capital market. This study concludes that alternative hedonism can underpin moral markets and contribute to the reproduction of inequality structures.

This study presented another side of the course of the hedonism lifestyle that explicitly described the main issue of the hedonism of the rulers in the Qur'an perspective.

\section{METHODS AND MATERIAL}

Researchers used library research related to hedonism in the perspective of the Qur'an. The researcher collected data related to the study both from primary and secondary sources such as the Qur'an, Hadith, Tafsir books, and books that were related to this research. The researcher used a multidisciplinary approach, namely, interpretation, history, and social. The method used in this research was the maudhu'i (thematic) method, which is a method in which the mufassir seeks to collect verses from the Qur'an from various surahs and those related to predetermined issues or topics. Mufassir then discusses and analyzes these verses' contents to become a unified whole (Shihab, 1995). Salim et al. (2012) outline seven steps that must be taken in using the maudu'i interpretation. The steps are as follows: a) Choosing or determining the problem of the Qur'an that will be studied maudhu'i. Researchers define hedonism in the Qur'an. b) Track and compile verses related to this issue. c) Arrange the verses coherently based on the chronology of their descent along with knowledge of the background of the asbab nuzul. d) Knowing munasabah between verses. e) Arranging the discussion theme in an appropriate, complete, perfect, and systematic framework. f) Complete the description and discussion with the hadith so that it is perfect and precise.

Semantically, maudhu'i interpretation means interpreting the Qur'an according to a particular theme or topic. Maudhu'i interpretation, according to the majority of scholars, is to collect all verses of the Koran that have the same purpose and theme (AlFarwawi, 1997).

All the verses relating to a particular theme are examined and compiled. Everything is explained in detail and thoroughly and is supported by arguments or facts that can be justified scientifically, whether 
the statements come from the Qur'an, hadith, or rational thought (Baidan, 2012). Al-Qur'an collects themes that need to be explored using the maudhu'i method. Interpreting the Qur'an with this method will be able to determine the appropriate shari'ah for each time and place (Hakim, 2006).

During the existence of the Qur'an, it was believed that dialogue would always be able to answer all the challenges of life, which were very diverse so that the values contained could be ideally realized. One of the ways have taken is interpreting the Qur'an with the madhu'i method (Suryadilaga, 2005).

This method's main characteristic is to highlight the theme, title, or topic of discussion, so some say it is a topical method. Mufassir will look for themes that exist in the community in the Qur'an or from others. The chosen themes will be thoroughly studied from various aspects according to the verses' instructions to be interpreted. Existing problems must be thoroughly and thoroughly studied in order to find a solution to these problems (Baidan, 2012).

\section{RESULTS AND DISCUSSION}

\section{Theory of Hedonism}

There are two categories of studying philosophy systematically, first theoretical philosophy, and second practical philosophy. Theoretical philosophy is worked by philosophers, whereas philosophers do practical philosophy. Sometimes a philosopher is not a philosopher. A philosopher is an academic and theoretical master of various philosophies' principles, history, and systems. A person may know many things about philosophy, but he cannot think of philosophy as a philosopher. Studying philosophy is no different from learning other sciences that require the performance of reason.

To understand philosophy theoretically, the philosophers divide into three main topics: historical, systematic, and principle. First, philosophy has historically been divided into classical, modern, and contemporary philosophy with the realm of study of Western, Eastern, and Islamic philosophy. Second, philosophy is systematically divided into discussions of branches and schools. Examples of units of philosophy are ontology, epistemology, and axiology. Examples of philosophical flow are materialism and idealism. The third philosophy is seen from the underlying principle. Philosophy can grow on two pillars of knowledge, namely: science and religion. The philosophy in philosophers' hands is because philosophers have a solid scientific foundation or indepth religious understanding.

Branches of Philosophy and Flow are as follows: a) Branch of Ontology. Ontology is a branch of philosophy that studies the nature of existence. In discussing this ontology, philosophy is divided into various streams such as monism, dualism, pluralism, spiritualism, materialism, mechanism, vitalism, and organism. b) Branch of Epistemology. Epistemology is a branch of philosophy that discusses knowledge. Epistemology consists of streams in rationalism, empiricism, realism, criticism, idealism, positivism, and pragmatism. c) Branch of Axiology. Axiology is the branch of philosophy that studies action. Axiology consists of tangible schools: Ethical Idealism, Ethical Deontologism, Teleological Ethics, Hedonism, and Utilitarianism.

Hedonism is understood as the philosophy of philosophy from Greece. The purpose of understanding this flow, of avoiding misery and enjoy happiness as much as possible in life in the world. At that time, hedonism still had a positive meaning. In 
its development, followers of this understanding seek happiness with long effects without suffering. They undergo various ascetic practices, such as fasting, living in poverty, even becoming ascetics to get real happiness. But when the Roman Empire controlled all of Europe and Africa, this understanding shifted negatively in hedonism's new slogan. The new motto, Carpe Diem (get as much enjoyment as possible while you live), animates each breath of the flow. Happiness is understood as mere pleasure without having a profound meaning.

The shallowness of meaning begins to be felt. Negative understanding is inherent and positive understanding disappears in hedonism. Because understanding hedonists who prioritize happiness is replaced by prioritizing pleasure. The notion of pleasure is different from happiness. Enjoyment tends to be more mundane than spiritual. Enjoyment is only after temporary things. The future is no longer unthinkable. The most important and meaningful moment is now, not the future or the past. Life is an opportunity that only comes once. Therefore, fill it with pleasure without thinking about the long-term effects that will be caused. If you think too much about the pros and cons of life, it will be in vain because every opportunity you have will be missed. That is the negative hedonist thought that is developing at this time. That thought seems to be very suitable for the lifestyle of modern society. Individuality and lust for enjoyment are very thick in coloring our lives. This understanding began to penetrate the lives of adolescents.

Hedonism is a view of life that assumes that pleasure and material enjoyment are the main life goals. For adherents of this understanding, having fun, sensuality, and satisfaction is the primary purpose of life, whether it is fun for others or not. Because they assume this life only once, so they feel they want to enjoy life as enjoyable as possible. In the environment of the adherents of this understanding, they live in the streets as freely as possible to fulfill unlimited lust. Their views are summarized in Epicurus's statement, who stated, "Cheer up to you today, satisfy your passions, because tomorrow you will die."

It was witnessed that at this time, most people, especially adolescents, were flocked to lead a life based on mere pleasure-seeking, one of which was in the form of the entertainment world. Perhaps, many of us are not aware of hedonism as a system of ethical philosophy that emerged in the West. Hedonism in English: hedonism, from the Greek word hedone (pleasure and enjoyment). Hedonism equates kindness with pleasure, and states that pleasure and happiness are the purpose of life and human action.

Flow related to hedonism: a) Cyrene with its founder Aristippus. b) Epicureanism and its founder, epikuros, according to him, the highest good in life is the absence of pain and the irritating pleasure that causes pain. The purpose of life is ataraxia: peace of body, mind, and spirit. c) Christian Epicureanism of Valla and Erasmus. d) Utopian epicureanism Sir Thomas More. e) Hobbes said that pleasure and pain arise from physical sources. f) Utilitarianism, with the characters Jeremy Bentham and John Stuart Mill. g) 18th-century French naturalist philosophy, Helvetius, Holbach, and De La Mettrie. h) All philosophy is naturalist and materialist, behavioristic psychology. i) Egoistic ethical hedonism assumes that humans always have to do in any way that will give him as much pleasure for themselves. j) Psychological hedonism holds that humans still do to fulfill their satisfaction. k) Universal ethical hedonism assumes that humans must always do to get the greatest pleasure in the long term.

The hedonistic paradigm focuses its view on the search for pleasure and avoidance of all suffering. But today, the substance no longer finds relevance. It 
seems that there is no common perception of anything that can bring pleasure and any activities that can bring suffering. The hedonistic philosophical essence sometimes has sexual connotations or liberal thinking.

Speaking of hedonism, we cannot rule out a Greek philosopher who is considered to have a significant role in building the epistemology of hedonism, namely Epicurus of Samos (341-270 BC), which later the principles of his teachings are known as Epicureanism. Epicureanism is a philosophical system originating from the teachings of Epicurus, which was coined around 307 BC. The essence of epistemology Epicureanism is built on three criteria of truth, namely sensation or aesthetic, pre-conception or prejudice, and finally feelings. Prolepsis is defined as "basic power" and can also be defined as "universal ideas", namely a concept and ideas that can be understood by everyone.

The word "man" is an example of how everyone has a preconceived notion of a man. Then the aesthesis or sensation (sensory responses) is interpreted as knowledge or knowledge gained through feelings and empirical verification. Like most modern science, Epicurean philosophy makes empiricism a tool to identify the truth of mistakes. The last feeling is more closely related to ethics than with the physical theory Epicurean, who will confirm that anything will give pleasure to humans, and anything will bring suffering. In this way, it is crucial to get a complete portrait of Epicurean ethical doctrine.

For Epicurus, the highest pleasure is tranquility (welfare and freedom from fear), which can only be obtained from knowledge, friendship, and simple life (virtuous and temperate life). He also acknowledged the feelings of simple pleasures (enjoyment of simple pleasures). Still, Epicurus interpreted pleasure as something that must be far from physical desires

(bodily desires), such as sex and lust. When we eat, he explained that we do not get too full and excessive because of dissatisfaction later. Thus, the consequence, later in the future, someone is not worthy of producing delicious foods.

Likewise, sex can encourage to increase lust or libido. But on the other hand, Epicurus assumed, too often, having sex would reduce sexual desire, which would result in the other party feeling dissatisfied with his sex partner and certainly causing unhappiness. Thus, worse, Epicureanism is trapped into another abyss, such as asceticism (understandings that practice simplicity, honesty, and willingness to sacrifice; ascetics, single life). Some consider epicureanism to be an ancient form of hedonism. Epicurus identifies 'pleasure' with 'tranquility' and emphasizes reducing excessive desire for the immediate acquisition of pleasure.

Therefore, according to Epicurus, pleasure is not basically fun, rather pleasure is a prosperous condition. He considered pleasure is relative. Thus, Epicureanism breaks away from the previous proposition: the highest good and the same benefits. Epicurus claims that the highest pleasures are achieved from simple life, such as a simple life lived with friends and philosophical discussions. He stressed that it is not a good thing if someone does something that makes someone else (a friend) feel good, which if the experience of the act someone just underestimates the experiences that will come and makes someone else feel no longer comfortable. Unfortunately, Epicurus did not explain his ethical, social system at length. In other words, the ethical, social system Epicurus was stuck at the level of functionalization.

\section{Basic Concepts}


The basic idea behind the hedonic meaning teaches us that every good action can be measured by how much pleasure and how little suffering can be produced. In the theoretical corridor, hedonism is also related to other ethical philosophy systems such as utilitarianism, selfishness, and permissive. In short terms, a hedonist will direct all his efforts to maximize this 'ratio' (pleasure over pain). A few centuries after Epicurus, came John Stuart Mill (18061873) a British philosopher utilitarianism and Jeremy Bentham (1748-1832), a British philosopher, who was also the founder of University College London (UCL), both of whom set several fundamental principles of hedonism based on the theory of hedonism ethical utilitarianism (understanding which says that humans in their actions are always looking for profit and benefit).

They said the values of utilitarianism are an essential foundation for establishing hedonism's philosophical values in all actions that lead to achieving the greatest happiness for all humans. Although consistent with the search for happiness or pleasure, there is little difference in the view of hedonistic values between Bentham and Mill relating to expostulates (ideas) about the principles of 'benefit' itself. There are at least two schools of thought regarding hedonism:

The first school, promoted by Jeremy Bentham, believes more in a quantitative approach. Bentham believes that the fundamental values of pleasure can be understood quantitatively. Basically, he believes that the values of pleasure can be spurred on by other pleasures that are affected by the duration of time (intensity). Thus, the amount of pleasure, intensity, and how long the pleasure can be enjoyed can also affect 'amount'. The second stream is vis a vis with the first group. It was represented by John Stuart Mill, who advocated a qualitative approach. Mill believes more that there are different pleasure levels, which are the highest quality of pleasure, better than the lower satisfaction rate. Mill also believes that more superficial beings, such as pigs, have the easiest way to obtain simple pleasures; as long as other life segments do not preoccupy them, they can easily obey their pleasures.

While the more complex creatures (elaborate beings), collide with a predisposition (tendency) to focus their attention on other problems (in life), therefore, get less time for pleasure. Thus, they (elaborate beings, Pen) will find it difficult to enjoy the 'simple pleasures' carried out by simpler beings in the same way and manner. But the problems that arise are: first, in general, every pleasure does not have the same nature or characteristics, even though the 'pleasure' can be seen as 'something fun' (pleasurable). After all, the standards that apply to what is said to be 'fun' vary. Such as sadism, which some people consider to be a pleasure and a hobby. The quantitative and qualitative approaches must be positioned and viewed as two complementary approaches. Second, someone will object if when someone else gets pleasure, maybe the other will feel suffering, which results in a contradiction about moral actions. It is a contradiction if we look at it from the perspective of a moral absolutist. Meanwhile, from the standpoint of moral relativity, there will never be a contradiction. In his book 'The Method of Ethics' (1963), these two problems are labeled by philosopher Henry Sidgwick as 'paradox of hedonism'.

Many see hedonism has nothing to do with egoism. But strangely, John Stuart Mill's utilitarianism is sometimes classified as a form of hedonism, which also justifies moral action through subsequent contributions to the highest benefits and happiness. It also - can be said - is the same as altruistic hedonism (altruism; understanding puts others first). Remember, some teachers do anything that can make someone's happy (via a long effort). Mill also approves actions that can make people happy-in other words, 
juxtaposing individualism with collectivism. It is true that Epicurus recommends us to pursue pleasure and happiness, but it must be remembered, he never taught that we must live a life of selfishness (selfish), which affects the obstruction of pleasure and happiness for others.

The discussion about hedonism in the philosophy above is very contrary to the Islamic principle of simplicity, humanity, and orientation to the hereafter. The implication of this understanding of hedonism has gained wide space and has become the pattern of life of modern society.

\section{Hedonism in the Qur'an Perspective}

The word al-Tarf in al-Quran is the word that is closest to the meaning of the word hedonism. Therefore it has the most extensive portion of interpretation compared to the others. The use of alTarf (hedonism) is not only used in matters of food and drink but also especially the authorities, officials, rich people and those in power than with their power and wealth and position beyond the limits set by Allah Almighty, such as positioning itself as God (like Pharaoh), boasting and reluctant to ask in the way of Allah (like Qarun), do homosexuals (like the Luth\}) and things that cross other limits.

The word al-Tarf in al-Qur'an with various forms, namely:

\section{QS. HUD/ 11:116}

"Thus, why are none of the people before you people who have the virtue that forbids (doing) damage on the face of the earth, except for a small portion among the people that We have saved among them, and those who do wrong Only concerned with the luxurious pleasures they have, and they are sinners?"

The mufradat's interpretation, according to Sa'labi, Laula is a specialty and in the form of an explanation because people like this do not get guidance (people who do not prevent the destructive actions), as where the previous people like the Prophet $\mathrm{Nu}$ has, and others. Ulu taqiyya is to have a reason, distinguish between rights and vanity, and hold fast to religion. That was said because the enforcement of Sharia was strong and initially weakened. Whoever has strong faith when weak is a person who is istiqamah, AlFasad is kufr and disobedience, this verse instructs people to prevent evil, but only a few can do this. Qalila shows only a few of them do disobedience and damage. Meanwhile, al-Mutraf is preoccupied with luxury and is kept away from the truth until they finally perish.

Al-Mutraf or will be written next with the words of the hedonists, are the dignitaries, the rulers who live in luxury, and use all the power and wealth that Allah Almighty follows only for their enjoyment. Their pleasures, pleasures, and excesses will gradually drag them into the abyss of destruction. This worldly pleasure is a mere mirage or mirage, which will be lost to age and death. All the luxury they boast about and show off at all cannot help them when the punishment of Allah Almighty comes upon them.

However, few people dare to prevent or even prohibit disobedience because of the magnitude of risk received if they dared to do that. When the perpetrators of disobedience and destruction are the rulers, most oppressed people do not dare to shout to stop the wrongdoing rulers. Indeed, only the elect are among the Prophets and messengers and their followers who dare to bet their lives to convey the truth from Allah. In these last days, the more obvious is disobedience and damage done by humans. Only 
those who believe in Allah Almighty and who are just and fair can prevent all disobedience and invite people to the path that Allah is pleased. In the interpretation of al-Syinqiti writes that there is a Sahih Bukhari Muslim Hadith from Usamah bin Zaid that the Prophet Muhammad said: There will come on the day of Qiyamat a man who is thrown into the fires of hell, such as spinning a donkey with his rope "then the expert of hell. Said: "O Fulan, did you not tell us to do good and prevent evil?" Fulan replied: "I told you to do well, but I did not do it and told you to prevent evil, but I came to him."

Thus, through His apostles, Allah Almighty reminded people, especially the religious leaders, the entrepreneurs, and the rich people, to carry out what they told the people to be in the form of goodness and leave all forms of disobedience and destruction. Not just talking, but behind, it all turned out they did all the damage and disobedience. These are they who forget one thing that Allah Almighty is the Almighty to see even the slightest and whatever disguised things they hide.

Studying and analyzing Qur'an seems to see with your own eyes how God Almighty destroys the people of Luth who are cursed by Allah Almighty. How did Allah overturn their homeland so that it was destroyed, then rain it with sijji rocks.

Even if you read the Date Tabari it is written that the Prophet Ibrahim forbade the earth to scorch the Luth\}, maybe there are still 50 Muslim items or less, but 10 of them are not Muslim, until Allah finally sent the Angels ie Gabriel, Michael, and Israfil to destroy them. Be thankful to Muhammad's people, where they get love from their Prophet, who is so patient and loves his people. So, he did not ask Allah to destroy his people; instead, he prays that Allah's people be given guidance. If today people do not believe, maybe their children or grandchildren will believe.

However, even though today the Muslims are the people of Muhammad, it is sunnatullah that the destruction will bear fruit. If humans no longer give warnings and punishments to their fellow men who violate the rules of Allah Almighty, God Almighty Himself, through His other creatures (the entire universe), will give punishment to anyone who does disobedience and destruction.

Meanwhile, in the Tafsir Khazin is written, (falaulakana min al-quruni mi qablikum) if those who have been destroyed before the people of Muhammad (ulubaqiyyah) have intelligence, obedience, and goodness (yanhauna 'a phase in fi. Al-Ard\}) prohibits damage on earth, this verse denounces those who do not prevent damage until finally, Allah Almighty destroy it (illa qali la) this is istisna 'munqati' which means little (minman anjainaminhum) from those whom I saved from the followers of the Prophet who prevented damage (wattaba'a allazina mautrifufihi wa kanumujrimin) i.e. those who wronged themselves by committing kufr, and disobedience which they enjoy excessively by leaving the delights of the afterlife and its pleasures and they are infidels.

At present, the damage has occurred everywhere. Not only the destruction of nature such as oceans and rivers polluted by waste, mountains, and forests that have been tripped to bare and barren to cause flash floods, as well as mining materials that are completely drained (exploited), to the ozone layer which is severely damaged which causes the earth's temperature to increase in heat and climate change which causes crop failure, all of which ends in the act of damage-for damage created by humans. Not only that, but even wrongdoers also destroy fellow humans with war-by-war, which resulted in the death of hundreds to perhaps millions of humans from ancient 
times until now. Modern weapons and chemicals and mass-murderous bombs were created for only one wish: "power". With that orientation, every means is done, even by spilling the blood of fellow human beings. Indiscriminately, both men, or women, children, and adults.

Then it is proper for such humans to be inferior to animals. Whereas animals only eat, drink and breed blindly like humans - the hedonic man. And wait where the doom will come suddenly to them, and they will be destroyed and disappear from the vanishing of this world. As in Ibn Kas's interpretation of QS. Hud/11: 116, as follows.

If the former people of good people prevented the ugliness and wickedness of the earth and only a few of them were saved by Allah from sudden anger and torment. This is Allah's command to obey Allah and prevent evil. If no one prevents the evil, then wait for the punishment of Allah Almighty will come suddenly with a fierce without them predicted, and Allah Almighty did not punish a people until they wrong themselves.

To do damage and to make suffering to others is tantamount to self-wrong. Humans are all siblings, both from any part of the world, whether from any religion, whether any race, from one father, Adam. However, most people inherit the sin of Qabil, who is hostile to other humans; envy, greed, and other vices make him justify any means to get what he wants, even to kill the life of his brother Abel.

\section{QS. AL- ISRA'/ 17:16}

"And if we want to destroy a country, then we command those who live in luxury in that land (to obey God), but they commit iniquity in that country, So it is appropriate to apply to the words (our provisions), then we destroy the country in ruins."

At this time, the destruction began to appear in life, such as humanitarian tragedies in various corners of the world, various rampant immorality, and intense natural damage such as forest fires and others. God has reminded all people to return to obedience to God, but many are reluctant until it is time for God to destroy their lives.

"And said the leaders who
disbelieved among his people and
who deniers will meet the
hereafter (future) and which We
have granted them in life in the
world: "(People) This is nothing
but a human like you, he eats
from what you eat, and drink
from what you drink."

In this verse, Allah asserted that the leaders who disbelieved in Allah and did not believe in the existence of the end (they were living in the world), scoffed at their Prophet, who had warned of the existence of great $a d z a b$. Suppose contextualized today is their ridicule to the preachers who give a warning of a reply from Allah. You have been neglected by boasting". That is, you have been neglected, turned away from the goal of eternal life. You are negligent and careless because the splendor of property has deceived you. To be proud of humans. However, it is a mere mortal world. "So that you pass through the graves", that is to say, and you are not converted so that you enter the grave and will not return to the world. Then throw away your age that has finished collecting wealth, looking for rank, looking for influence and position. Linguists give the name of the grave expression "porch of the afterlife". "Never!", That is to say, that your life is neglected because of accumulating wealth; luxury is not 
commendable. "Even you will know later". Someday you will know that your actions are of no avail.

"Then that," you emphasize once again, "once in a while" is not true that your attitude, "Even you will know later". That all your actions to collect wealth and boast is nothing. In the afterlife, all that won't help. According to some scholars, the third verse is a notification that you will be asked later which shirt you are, what rank you are, and which greatness you are arrogant about. Is not it just a body wrapping shroud? In the fourth verse also warned that the grave continues until the Day of Judgment. At that time, you will see that the world's wealth that you are proud of has no meaning at all, which means only practice for the afterlife.

Thus, Allah condemns people who apply hedonism so that he will get doom from Allah Almighty. Indeed, the behavior of exceeding the limit in using the pleasure facilities that God has provided is basically to commit wrongdoing both for oneself and others. It is a warning to all people that rights must be given to fellow human beings. A simple attitude and love for fellow human beings will bring happiness in this world and the hereafter.

\section{CONCLUSION}

It has been found in the Qur'an that Allah Almighty has prohibited hedonistic, materialistic, and exaggerated behavior. The Apostles also sent that warning so that humans would be safe, but most people refused. Until finally, they perished as a result of their actions. The stories of the previous people who were destroyed due to human hedonistic behavior are recorded in the Qur'an, such as the story of the Prophet Noah, the Prophet Luth (as), the Prophet Salih (as), the Pharaoh, and others. Taking a lesson from the verses of the prohibition of hedonism, this is very relevant so that humans do not carry out hedonistic behavior that will destroy their lives.

\section{REFERENCES}

[1]. Al-Farmawi, A. H. (1997). Al-Bidayah Fi AlTafsir Al-Maudhu'i. Mesir: Dirasat Manhajiyyah Maudhu'iyyah.

[2]. Anggraini, D. F. (2019). Night Clubber Hedonism Students and Lifestyle (Towards Student Behavior Pattern at Night Club Entertainment Places in Malang City. Socia Jurnal Ilmu-Ilmu Sosial, 16(2), 172-186

[3]. Baidan, N. (2012). Metodologi Penafsiran AlQur'an (Cet. IV). Yogyakarta: Pustaka Pelajar.

[4]. Caruana, R., Glozer, S., \& Eckhardt, G. M. (2020). Alternative Hedonism: Exploring the Role of Pleasure in Moral Markets. Journal of Business Ethics, 166: 143-158

[5]. Hakim, M. B. (2006). Ulumul Quran, translated by Nashirul Haq et al. Jakarta: Al-Huda.

[6]. Putra, P. D., Harahap, K., \& Rahmah, S. C. (2020). The Hedonism Lifestyle, Financial Literacy and Financial Management among Business Education Students to Financial Management. Journal of Community Service and Research, 4(1), 32-38

[7]. Salim, A. M., Mardan, \& Abubakar, A. (2012). Metodologi Penelitian Tafsir Maudu'i. Jakarta: Pustaka Arif

[8]. Saputri, A. \& Rachmatan, R. (2016). Religiusitas dengan Gaya Hidup Hedonism: Sebuah Gambaran pada Mahasiswa Universitas Syiah Kuala. Jurnal Psikologi, 12(2), 59-67

[9]. Shihab, M. Q. (1995). Membumikan al Qur'an: Fungsi dan Peran Wahyu dalam Kehidupan (Cet. XI). Bandung: Mizan.

[10]. Subawa, N. S., Widhiasthini, N. W., Pika, P. A. T. P., \& Suryawati, P. I. (2020). Hedonism on the Behavior of Consumer Society as a Global Cultural Transformation. International 
Research Journal of Management, IT \& Social Sciences, 7(2), 59-70.

[11]. Suryadilaga, M. A. (2005) Metodologi Ilmu Tafsir (Cet. III). Yogyakarta: Teras

\section{Cite this article as :}

Mustaqimah, Muhammad Obie, "The Hedonist Life of the Rulers in the Qur'an Perspective", International Journal of Scientific Research in Science and Technology (IJSRST), Online ISSN : 2395-602X, Print ISSN : 2395-6011, Volume 7 Issue 6, pp. 222-233, November-December 2020. Available at doi $\quad$ : https://doi.org/10.32628/IJSRST207628

Journal URL : http://ijsrst.com/IJSRST207628 